\title{
Analyzing Application of Information Communication Technologies and Use for Information Provision by Library Staff of Mount Kenya University Library, Kisii Campus
}

\author{
Wamalwa Lucas Wanangeye*, Benard Omallah George \\ Mount Kenya University-Kisii Campus, Kenya
}

Copyright $(2016$ by authors, all rights reserved. Authors agree that this article remains permanently open access under the terms of the Creative Commons Attribution License 4.0 International License

\begin{abstract}
Information and Communication Technologies (ICTs) play a crucial role in creating access to and utilization of library information resources and services through the use of library management systems leading to the current stampede to train and refresh library staff skills in order to promote and engender service delivery. When academic libraries integrate ICTs in acquisition, processing, storage, dissemination and accession to their holdings, user needs are addressed quickly and on time. In this study the researchers sought to determine the application of Information Communication Technologies (ICTs) and Use for information provision by library staff of the Mount Kenya University Library, Kisii Campus. The target population was Mount Kenya university library staff and students. A survey research design aimed at identifying users' views and interpretation of the application and use of ICTs in the provision of library information resources and services. Stratified sampling was used to identify the students-respondents and purposive sampling used to select the library staff. While questionnaires were placed to collect the data from students, library staff respondents were interviewed. The study sample comprised four hundred (320) library users and staff out of a population of three thousand five hundred and twenty eight (1456). The study showed among other findings, that there are improved access and use of library resources and services through the use ICTs in Mount Kenya University, Kisii Campus.
\end{abstract}

Keywords Information and Communication Technologies, Library Resources and Services, Library Management System, Academic Library

\section{Introduction}

Information communication technologies (ICTs) in the information world have brought about some major changes. According to La! ICTs are: "a diverse set of technological tools and resources used to communicate, and to create, disseminate, store and manage information" (cited in Chisenga (2001:3) According to Chisenga (2001:3) "ICTs came about as a result of the digital convergence of computer technologies, telecommunication technologies and other media communication technologies". Munoo (2000: 1) goes on to say "the drive towards globalization of ICTs which involve computer hardware and software, radio and television receivers, broadcasting and telecommunications equipment and networking, and multimedia systems has created new technologies, products and services." Chisenga (1999:2) pointed out that "ICTs if properly harnessed, can play an important role in the development of the continent". The use of ICTs in general, and the computer and Internet in particular, enable library resources all over the world to be accessed rapidly.

Developments in microcomputers and telecommunications led to the growth of ICTs applications. Abbas (1997) argued that the use of ICTs has changed the roles and culture of libraries and library workers. ICTs play an important role in information and knowledge management. Technology has the potential to allow more useful and valuable services to be produced than have previously been available. The appetite and expectation of the library users has increased because of ICTs, and academic library workers are facing new challenges because of the rapid technological advances. They are experiencing escalating expectations and demands from the library users. It is therefore especially important for university libraries whose core asset is information, to instantly respond creatively and dynamically to all these changes. Information and communication technology (ICT) started developing in the 19th Century.

Knowledgeable librarians seem to be the key to the whole 
process. Therefore ICTs skills are essential for all levels of library workers and the traditional library core courses taught in library and information science schools in the past years. Even though there is so much emphasis on ICTs, paper print books will remain important in libraries. According to Stover (1999: 11) books have their own advantage of being able to be browsed, and they are portable 1nd therefore have a large base for users. Print and electronic information will continue to coexist for the foreseeable future.

The modern library must be equipped to ensure fast and up to date provision of information. The demand for library service has increased over the last few years with ICTs having transformed the services. The content and programs of the universities have been transformed, and there have been significant infrastructural developments within libraries. Setting up ICTs takes a lot of work, but once implementation has been done and the library workers have been trained, it enables the staff to be knowledge workers and therefore become creative and more productive even though they bring their own problems.

\section{Literature Review}

ICTs are more than just another tool. Their potential for increasing the range, relevance and accessibility of information and communication used in libraries is very significant as well as their potential for supporting library staff in their everyday role and for continuing training and professional development. The use of ICTs facilitates storage of information in CD-ROMs, digital versatile disc (DVD) and other electronic media. Furthermore, ICTs can be used to integrate or repackage information from different sources that can then be distributed (Chisenga 2001: 6).

Libraries are among the major information providers in most countries. They need to be in the forefront in terms of using the latest efficient information storage and disseminating technology to deliver services to the users. To prepare information professionals, there must be an assessment of the librarian's role in the new electronic information environment. The library workforce then needs to be provided with the necessary skills to effectively assume that role. According to Meadows, Gordon and Singleton (1982: 1), some libraries are making a "transition from traditional communication channels to digital channels". However the major drivers of the changeover are information collection, analysis, storage, retrieval, distribution and dissemination.

Library employees have been trained to understand the content of information resources, to understand technology and to understand people. Library workers face tremendous pressure to fulfill their traditional role and to utilize the latest technology to radically restructure conventional library functions. Stover (1999:9) argued that: the library is a place that clearly must stay grounded in history, but at the same time we must prepare for the changes that inevitably await us. Just as the old cannot survive without the new, so the new must not become disconnected from the old.

The information society has brought about changes in the traditional skills of library workers. According to Steele and Guha (1999): employees will be involved in a lifelong learning process; be able to process and apply information to the satisfaction of their client communities, be able to market information and have high level of expertise as appropriate in information technologies. Desai (2002) qualifies the above statements by saying: Librarians are most interested in instructional techniques and technologies and in the teaching of information literacy in the sciences. They are also interested in learning more about electronic resources, including selections, management, and impact.

Library workers are no longer relying only on their traditional skills, but they are now looking at having more ICTs skills in order to be of more assistance to the library users. Simmonds and Andaleeb (2001:631) argued that in finding a way of familiarizing users with the library, there is need to have access to helpful and knowledgeable library staff. Users will be able to effectively use library resources if they fully utilize the ICTs tools.

Knowledgeable librarians seem to be key to the whole process. Therefore ICTs skills are essential for all levels of library workers and the traditional library core courses taught in library and information science schools in the past years. Even though there is so much emphasis on ICTs, paper print books will remain important in libraries. According to Stover (1999: 11) books have their own advantage of being able to be browsed, and they are portable 1nd therefore have a large base for users. Print and electronic information will continue to coexist for the foreseeable future.

The modern library must be equipped to ensure fast and up to date provision of information. The demand for library service has increased over the last few years with ICTs having transformed the services. The content and programs of the universities have been transformed, and there have been significant infrastructural developments within libraries. Setting up ICTs takes a lot of work, but once implementation has been done and the library workers have been trained, it enables the staff to be knowledge workers and therefore become creative and more productive even though they bring their own problems.

\section{Research Methodology}

This study aimed at determining the application of the available ICTs and their use in provision of information Mount Kenya University Library. Data was obtained to:

1 Identify utilization and limitations to the use of ICTs;

2 To solicit the views and impression the library staffs have concerning their ICTs utilization and limitations; and.

3 To establish what should be done to maximize the utilization of ICTs.

According to Bless and Higson-Smith (1995:63), a 
research design "is a specification of the most adequate operations to be performed in order to test specific hypothesis under given conditions". Research design revolves around surveys, experimentation and case studies. Mouton (1998:208) describes experimental research as taking action and observing the consequences of that action. According to Rowley (2002: 16) the case study research seeks to undertake a modest scale research project based on a workplace or a comparison of a limited number of organizations. Case studies are able to achieve in sights that are not possible with other approaches; they are useful for preliminary exploratory stage of a research project and as a basis for a more structured tool necessary in surveys. Yin (1994: 13) identifies the strength of a case study as its ability to investigate a phenomenon in its context. Rowley (2001: 17) identified that a case study research "uses a variety of evidence from different sources, such as documents, artifacts, interviews and observations". The case study was conducted using survey research.

Survey research involves "obtaining information directly from a group of individuals" (Dane 1990: 120).

In the context of this study, a survey method was appropriate because the study required the collection of data on the opinion and views of library staffs of Mount Kenya University Library. Survey research is the most appropriate methodological approach for this type of study given the nature of the research problem and purpose of the study. According to Dane (1990: 120), survey research "involves obtaining information directly from a group of individuals"; in this study information was obtained from Mount Kenya University Library staffs.

The population in this study was library staffs of Mount Kenya University Library who have undergone formal training and deal with library readers on a day-to-day basis. Bless and Higson-Smith (1995: 86) indicated that the population parameters are "specific value of quantities that relates to the population, such as the average age of all primary school teachers." For this research, it is library staffs that have undergone formal university training, be it one year or four years. The trained university library staffs were numbered 88. Bless and Higson-Smith (1995: 87) argued that, the best way to get an accurate picture is to examine each and every member of the group being researched; this was done in the present study. According to Bless and Higson-Smith (1995: 85), "it is also possible to reach accurate conclusion, by examining only a portion of the total group". Leedy (1997:211) pointed out that "for smaller population, $\mathrm{N}<100$, there is little point in sampling. Survey the entire population".

There was a physical assessment of the available ICTs resources in the library, with the assistance from the relevant supervisors and the senior systems librarian, informal interviews were carried out to collect data from the library staffs. Published and unpublished sources were used to collect additional data relevant to the study. Most of the data was collected by means of a self-administered questionnaire at Appendix B. The questionnaire was used to identify the knowledge and skills in the use and application of ICTs for information provision by Mount Kenya University Library staffs. The staffs' needs were identified as well in order to promote full utilization of the available ICTs efficiently and effectively during information provision.

Questionnaires were hand delivered to library staffs in the main campus and the Faculty of Engineering and Technology Library. According to Leedy (1997:187), questionnaire's main disadvantage is a low response rate. In order to improve the response rate reminders were sent to those who received questionnaires by electronic mail and a follow up was made to those who received them by hand.

Eighty-eight questionnaires were distributed by hand and through e-mail, 67 questionnaires were returned. The respondents were the library staffs who had undergone formal training and obtained a certificate, diploma, degree and masters and dealt with library users in their daily duties. A date was set for collection of the questionnaires. A total of $67(76.13 \%)$ usable questionnaires were received back. The returned questionnaires were sight-edited to eliminate those that were not usable, and were post-coded to prepare for the net response rate as proposed by Alreck and Settle (1995:207). The response rate was according to Babbie's analysis very good. Babbie (1991:267) pointed out that a response rate of 50 percent is adequate, 60 percent is good, and 70 percent is very good and adequate for analysis and reporting.

Alreck and Settle (1995:267) describes data analysis as "the use of statistical tools in order to reduce the amount of details in the data, summarizing it and making the most important facts and relationships apparent". Variables were distinguished and entered into the provided SPSS table. Alerck and Settle (1995:268) describes variables as "data from each individual survey questions because they vary from one person to the other". SPSS is a program used for analyzing statistics and managing data. Variables are analyzed into the collected data's frequencies, percentages and cross-tabulation Responses were coded beginning with 1, in a case where there were multiple responses, the first response was coded 1 and the second was coded 2 and the third was coded 3 and so forth. Data was manually entered into the SPSS Data Editor. SPSS generates data to make it easy for analysis. The next chapter presents the data that was generated. Frequency tables were generated to express percentages and charts were also used to display categorical distribution graphically.

According to Powell (1991: 164) the content analysis approach is best used for the responses for open-ended questions, and this was the method adopted in this research. Content analysis is collecting, organizing information systematically in a standard format that allows analysts to draw a conclusion about the characteristics and meaning of recorded material (Alreck and Settle 1995:271). Content analysis was made for open-ended questions; major themes were drawn from the diverse responses. Dane (1990: 154) describes content analysis as a methodology used for determining the content of written recorded or published 
communications via a systematic, objective and quantitative procedure. It is collecting, organizing information systematically in a standard format that allows analysts to draw a conclusion about the characteristics and meaning of recorded material. It is useful for tabulating the results of open-ended questions.

\section{Results and Discussions}

The purpose of this study was to determine the application of ICTs and use by the library staffs of Mount Kenya University Library. It surveyed staffs in their work situation. The objectives of this study were: to establish the type of ICTs used in Mount Kenya University Library; to determine the purpose for which ICTs were used; to determine the ICT skills and knowledge of Mount Kenya University Library staffs; to establish how the staffs of Mount Kenya University Library gained their ICT skills and knowledge; to identify Mount Kenya University Library staff's training needs; and then give recommendations on how ICTs could be effectively and efficiently utilized to maximize information provision in Mount Kenya University Library.

\section{Characteristics of the Study Sample}

This section deals with demographic information of the respondents, such as gender, academic qualifications, present occupation and positions, and experience.

\section{Gender}

The respondents were asked to indicate their gender in order to identify the gender distribution of the study population. Table 2 shows that the female respondents were $45(67.2 \%)$ compared to $22(32.8 \%)$ males.

Table 1. Gender

\begin{tabular}{|c|c|c|}
\hline GENDER & FREQUENCY & PERCENT \\
\hline FEMALE & 45 & 67.2 \\
\hline MALE & 22 & 32.8 \\
\hline TOTAL & 67 & 100 \\
\hline
\end{tabular}

Source: Primary

\section{Academic Qualifications}

The respondents were asked to indicate their academic qualifications in order to get their formal educational background in relation to their work. This was with the knowledge that the respondents have all undergone formal university training. Information given in Table 3 regarding the respondent's professional qualifications showed that only three have a Certificate in Librarianship, 37 had a diploma in Librarianship, three had both a diploma in Librarianship and a degree from other subject disciplines, and the holders of Masters in Librarianship were 24.

The masters' degree holders accounted for 35.8 percent, while first degree and certificate holders accounted for 4.5 percent each, and diploma holders accounted for 55.2 percent. Mount Kenya University Library used to train its entire staff up to master's degree, but has since changed its policy and is now training those recruited with high school certificate up to undergraduate diploma level, while those recruited with first degree are trained up to master's level.

Table 2. Academic Qualifications

\begin{tabular}{|c|c|c|}
\hline $\begin{array}{c}\text { ACADEMIC } \\
\text { QUALIFICATIONS }\end{array}$ & FREQUENCY & PERCENT \\
\hline CERTIFICATE & 3 & 4.5 \\
\hline DIPLOMA & 37 & 55.2 \\
\hline DEGREE & 3 & 4.5 \\
\hline MASTERS & 24 & 35.8 \\
\hline TOTAL & 67 & 100.0 \\
\hline
\end{tabular}

Source: Primary

\section{Present Position and Area of Work}

According to the data collected and analyzed in Table 4 below, there are thirty eight $(56.7 \%)$ library officers, five $(7.5 \%)$ library supervisors, fifteen $(22.4 \%)$ librarians and nine $(13.4 \%)$ senior librarians.

Table 3. Post Held

\begin{tabular}{|c|c|c|}
\hline POST HELD & FREQUENCY & PERCENT \\
\hline Library Officer & 38 & 56.7 \\
\hline Library Supervisor & 5 & 7.5 \\
\hline Librarian & 15 & 22.4 \\
\hline Senior Librarian & & 13.4 \\
\hline Total & 67 & 100.0 \\
\hline
\end{tabular}

Source: Primary

The respondents were also asked to indicate their present area of work. This was meant to identify the type of routine jobs ICTs are used for depending on their work position in the library. The data collected and analyzed indicated that the library workers work in various areas. Graph A below shows that the circulation assistants are nineteen (28.4\%), cataloguing assistants are nine (13.4\%), acquisition assistants are six (9\%), periodicals assistant are three (4.5\%), inter library loans assistants are three (4.5\%), the automation assistant is one (1.5\%), MKU Documents and Special Collection (MKU-DSC) are two (3\%); and subject librarians are $24(35.8 \%)$. The subject librarians are each responsible for at least two to three academic subjects offered by Mount Kenya University.

\section{Experience}

The respondent's work experience in Mount Kenya University Library was sought. The data on Table 5 shows 
that 23.9 percent of the respondents have 1-5 years' experience, 40.3 percent account for those respondents with experience of 6-10 years, 16.4 percent have 11-15 years' experience, 10.4 percent have $16-20$ years, six percent have 21-25 years and three percent have 26-30 years.

According to the informal interviews, most of the respondents who have experience of 16 years and more were recruited with the minimum entry qualifications of high school certificate and junior certificate. It is most prevalent for the library staffs who were recruited with a minimum of a degree to leave Mount Kenya University Library after some time for other libraries or change professions. The majority of the respondents have worked for Mount Kenya University Library only, for instance, 40 (71.6\%) had never worked in other libraries while only 19 (28.4\%) have worked in other libraries.

Table 4. Experience

\begin{tabular}{|c|c|c|}
\hline EXPERIENCE & FREQUENCY & PERCENT \\
\hline $0-5 \mathrm{yrs}$ & 16 & 23.9 \\
\hline $6-10 \mathrm{yrs}$ & 27 & 40.3 \\
\hline $11-15 \mathrm{yrs}$ & 11 & 16.4 \\
\hline $16-20 \mathrm{yrs}$ & 7 & 10.4 \\
\hline $21-25 \mathrm{yrs}$ & 4 & 6.0 \\
\hline $26-30 \mathrm{yrs}$ & 2 & 3.0 \\
\hline TOTAL & 67 & 100.0 \\
\hline
\end{tabular}

Source: Primary

In order to identify what ICTs are they available to, and how they are used for provision of information. The analysis was as follows:

\section{Access to Information \\ Communication Technologies}

Table 6 provides the data on the availability of ICTs and access to computers that are commonly used in libraries. The data analysis shows that all the respondents have access to computers. This data was collected in order to identify what ICTs were available and to how many respondents. Those who had access to both personal and terminal computers were $35(52.2 \%)$, and four (6\%) shared computers. Staffs who indicated that they use terminal computers are three (4.5\%). All the senior library staffs have personal computers, while the cataloguing and acquisitions assistants have personal computers too, although at times they have to share them with other workers.

According to the senior systems librarian, Mount Kenya University Library has managed to provide its staffs with Hewlett and Packard and Dell computers in order to be in line with the latest emphasis of using ICTs to provide library services in today's libraries. The researcher also observed that the library had two document scanners, barcode scanners for the circulation, cataloguing and ordering sections, microfilm and microfiche readers, televisions, video machines, videos, a telephone line in every office, telex-fax machines, shared printers for all the computers, and two audio systems. Data analysis shows that the computers in Mount Kenya University Library have Windows 2000, 98 and Windows NT. These ICTs are for use inside Mount Kenya University Library only.

Table 5. Access to Information and Communication Technologies

\begin{tabular}{|c|c|c|}
\hline ICTs Access & Frequency & Percent \\
\hline Personal Computer & 25 & 37.3 \\
\hline Terminal Computer & 3 & 4.5 \\
\hline Shared Computer & 4 & 6.0 \\
\hline Personal and Terminal & 35 & 52.2 \\
\hline Total & 67 & 100.0 \\
\hline
\end{tabular}

Data received through interviews and observation shows that all library staffs had access to the Internet and World Wide Web, the intranets (Mount Kenya University databases) and extranets (databases outside Mount Kenya University) for their computers. The networking systems of the Mount Kenya University Library are the local area network (LAN); Online Computer Library Centre (OCLC) database that is an American based Institute; and the US Machine Readable Cataloguing Record (USMARC) bibliography. All the library staffs are connected through the LAN but not all of them have a connection with other networks like OCLC. According to the interview, all junior staff (those who do not have masters) in the ordering and cataloguing sections had OCLC connection but not all senior staff had those databases because they do not order and catalogue library material.

\section{Utilization of Information Communication Technologies}

This section is an analysis of the interview and questionnaire data on the library staff efficiency and effectiveness in using the available ICTs in their work place. According to the data analyzed, even though all library staffs have access to ICTs the junior staffs hardly use the ICTs for anything else except their routine jobs because they work on targets and have to produce a specified statistical output at the end of the day. The junior library staffs use computers for their routine jobs like cataloguing, ordering, issuing and returning of library material at all times in their job to an extent that if the computers are down they cannot do any work. Senior library staffs use and apply a number of ICTs' resources and at the same time have hands on practice and get trained in the process.

\section{Access and Use of Information Communication Technologies}

The respondents were asked to indicate the ICTs' resources they had access to in order to try and identify the skills they had and identify their limitations in using the available tools. According to Table 7, all the 67 respondents 
are able to access and use online public access catalogue (OPAC), 37 respondents could scan draw and design, and photocopying and printing services could be done by 32 respondents. Respondents who could do cataloguing and acquisitions using ICTs were 54, 50 respondents could operate the integrated circulation systems, 53 respondents could operate the compact disk read only memory (CD-ROM). The majority used the e-mail tool that accounted for 66 respondents; the image archive could only be used by ten respondents and therefore not very popular. Forty respondents could use the resource sharing electronic library, and 62 respondents could use Internet and the World Wide Web. Only four respondents could use video conferencing facilities, Braille specialist software was found to be not known by any respondent. The respondents that were able to make links to specific subject gateway were 37 . The data analysis indicates that the ICTs resources the respondents have access to and used were those they used for their daily work, as well as e-mail that are used for the institutional communication and private communication.

Table 6. Access to and Use of The Following

\begin{tabular}{|c|c|c|}
\hline Access and Use of following & Frequency & Percent \\
\hline OPAC & 67 & 100 \\
\hline Scanning Drawing \& Design & 37 & 55.2 \\
\hline Photocopying and Printing & 32 & 47.8 \\
\hline Cataloguing \& Acquisition & 54 & 80.6 \\
\hline Integrated Circulation System & 50 & 74.6 \\
\hline CD-ROM & 53 & 79.1 \\
\hline Email & 66 & 98.5 \\
\hline Image Archive & 10 & 14.9 \\
\hline Resource Sharing & 40 & 59.7 \\
\hline Access \& Use of following & Frequency & Percent \\
\hline Internet and WWW & 62 & 92.5 \\
\hline Video Conferencing & 4 & 6 \\
\hline Braille specialist software & 0 & 0 \\
\hline Links specific subjects \\
gateways
\end{tabular}

\section{Previous Training in Information Communication Technologies}

Data on training of the respondents (see Table 8), shows that $31(46.3 \%)$ were trained on the use of ICTs available in the library. Those who had not had training in ICTs were 26 $(38.8 \%)$. Some respondents got their ICTs training while they were doing their diplomas in information studies and those account for six $(9 \%)$ while the ones who got it when they were doing masters degrees account for four $(6 \%)$.

The majority of the respondents who have had training in ICTs had in-house training. Some had computer knowledge they learnt from their colleagues; and some enroll on their own for courses offered by other institutions. A few senior library staffs have gone for ICTs training course or workshops as mentioned below, and some even indicated that they wish they could be trained on routine library programmes so that they are not rendered helpless when they experience problems after working hours.

Apart from being trained on the programmes that the library used, data analysed show that some library workers attended short courses and workshops on the following:

- Two respondents trained on PowerPoint;

- Two respondents trained on library systems;

- Two respondents were trained on e-mail;

- Seven respondents attended a course on Internet;

- Four respondents attended a CD-ROM course;

- One respondent did a course on hypertext mark-up language (HTML);

- Two respondents trained on index and database access;

- One respondent did records management;

- Three respondent were trained on US Marc and OCLC;

- One respondent did hands-on practice and theory on online resources;

- Two respondents did web use and design.

- The only respondents who were trained on the above-mentioned ICTs were seven library workers who seem to enjoy a monopoly over training courses.

Table 7. Previous ICTs Training

\begin{tabular}{|c|c|c|}
\hline Previous ICT Training & Frequency & Percent \\
\hline YES & 31 & 46.3 \\
\hline No & 26 & 38.8 \\
\hline Diploma & 6 & 9.0 \\
\hline Masters & 4 & 6.0 \\
\hline Total & 67 & 100.0 \\
\hline
\end{tabular}

\section{Skills and Knowledge for Application and Use of ICT's within the Library}

The respondents were asked if they had skills in some of the ICTs' resources that are commonly used in libraries. This was to try and find out what resources they are able to use in their work. The respondents use the routine work programmes as reflected by Table 9 . E-mail use was by 66 $(98.5 \%)$ respondents, $61(91 \%)$ respondents searched the WWW, 54 (80.6\%) respondents used Microsoft Word, 52 $(77.6 \%)$ respondents catalogued, $48 \quad(71.6 \%)$ used circulation control, $42(62.7 \%)$ did a reference service using online tools, and $39(58.2 \%)$ used the resource ordering program.

The following ICTs applications are not used as much as the above mentioned by the respondents, these includes journal control which was used by $17(25.4 \%)$ percent, and inter library loans (ILL) could be done by 24 (35.8\%) of the respondents. Journal control and inter-library loans have fewer staff than other departments such as circulation and cataloguing, and those library staffs are the only ones who 
have been trained on the job to use those programmes.

According to an informal interview held with the head of circulation, fines control is a very sensitive module because it deals with financial affairs and therefore only 18 (26.9\%) respondents knew how to operate it. The rest of the ICTs' resources like enrollment in online courses was done by eight (11.9\%) respondents, the use of online discussion forum could done by $23(34.3 \%)$ and the use of video conferencing could be done by four $(6 \%)$. The respondents who had skills for the above three mentioned tools, online courses, online discussion forum and video conferencing were mostly expatriates who got training from the libraries they worked in before.

Table 8. Skills in Information and Communication Technologies

\begin{tabular}{|c|c|c|}
\hline SKILLS IN ICT & FREQUENCY & PERCENT \\
\hline Circulation Control & 48 & 71.6 \\
\hline Cataloged & 52 & 77.6 \\
\hline Ordered & 39 & 58.2 \\
\hline Journal Control Order & 17 & 25.4 \\
\hline Fines Control & 18 & 26.9 \\
\hline Inter Library Loans & 24 & 35.8 \\
\hline Reference services & 42 & 62.7 \\
\hline Microsoft word document & 54 & 80.6 \\
\hline Used Email & 66 & 98.5 \\
\hline Searched the Web & 61 & 91 \\
\hline Enrolled for online course & 8 & 11.9 \\
\hline Online discussions & 23 & 34.3 \\
\hline Video Conferencing & 4 & 6 \\
\hline
\end{tabular}

\section{Training Needs}

The respondents were asked to identify their ICTs training needs in order to determine if training was needed and what in particular was needed. The respondents were given a choice of the types of training needs and as indicated by Table 9. Understanding the theory, practice and pedagogy of online learning was chosen by $35(52.2 \%)$, increasing awareness for locating online resources there were also 38 $(56.7 \%)$, for evaluating online learning material there were $38(56.7 \%)$ and for designing and developing new online materials there were $29(43.3 \%)$ respondents. Some of the respondents indicated that they were not familiar with the listed programmes and therefore could make the best choices.

Table 9. Training Respondents would benefit from

\begin{tabular}{|c|c|c|}
\hline Training to benefit from & Frequency & Percent \\
\hline $\begin{array}{c}\text { Understanding he theory, practice and } \\
\text { pedagogy of online learning }\end{array}$ & 35 & 52.2 \\
\hline $\begin{array}{c}\text { Increasing your awareness locating online } \\
\text { resources }\end{array}$ & 20 & 22.9 \\
\hline Evaluating existing online learning material & 38 & 56.7 \\
\hline Designing and developing new online material & 29 & 43.3 \\
\hline
\end{tabular}

\section{Online Resources Training That Will Improve Their Work}

In order to determine the perception of the respondents on what they thought could improve their work they were asked to indicate the online resources that they perceived to be key to the improvement of their work. Table 11 highlights the analysis of the finding information on the web were 41 $(61.2 \%)$ respondents and was the majority;

- Online assessment exercises were 39 (58.2\%) respondents and were the second most popular.

- Electronic discussion lists were 29 (43.3\%) respondents;

- Authoring online learning material were 28 (41.8\%) respondents;

- E-mail could help improve their work were 27 (40.3\%) respondents;

- Video conferencing were 26 (38.8 \%) respondents.

There was an open-ended question asking respondents to add what other areas they could think of that would improve their use and applications of ICTs they can think of that will improve their work apart from the above listed ones, only four $(6 \%)$ indicated the following:

- Digitalization

- Word processing and

- An introduction to library ICTs course, respondents' answers. Those who thought:

Table 10. Online Resource Training that will improve work

\begin{tabular}{|c|c|c|}
\hline Online Resource Training & Frequency & Percent \\
\hline Email & 27 & 40.3 \\
\hline Electronic Discussion List & 29 & 43.3 \\
\hline Video Conferencing & 26 & 38.8 \\
\hline Web Information & 41 & 61.2 \\
\hline $\begin{array}{c}\text { Authoring Online learning } \\
\text { material }\end{array}$ & 28 & 41.8 \\
\hline Online Assessment exercise & 39 & 58.2 \\
\hline Any other resource & 4 & 6 \\
\hline
\end{tabular}

The respondents were asked to suggest the type of training they would find suitable. The respondents indicated how they would like to have their training in future. Table 12 shows the frequency distribution of the number of respondents according to what they prefer. A traditional face-to-face workshop was chosen by $54 \quad(80.6 \%)$ respondents, they indicated that they prefer it because one is able to ask questions and have the trainer go back and repeat what was missed. The respondents who chose an advice by phone were $23(34.3 \%)$ because they prefer learning at their own pace and in their privacy. An open or flexible learning online was chosen by $42(62 \%)$ respondents because it would still be part of ICTs training, they should be able to learn online. The other training needs the respondents had varied and were many. They have training needs in:

- Web design 


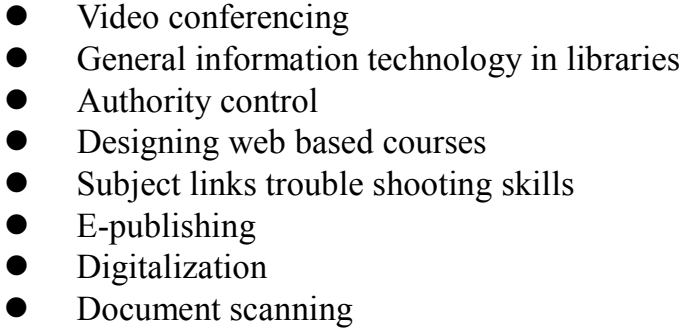

The respondents indicated that except for only a few, none had ever attended any 1CTs training in a form of workshop or course except on the programmes they use for their jobs.

Table 11. Preferred mode of acquiring information communication technology skills

\begin{tabular}{|c|c|c|}
\hline Recommendation & Frequency & Percent \\
\hline Traditional face to face workshop & 54 & 80.6 \\
\hline $\begin{array}{c}\text { Advice by phone, email, or through } \\
\text { electronic discussions }\end{array}$ & 23 & 34.3 \\
\hline Open or flexible learning online & 42 & 62.7 \\
\hline
\end{tabular}

\section{Conclusions and Recommendations}

Mount Kenya University Library is going through rapid technological changes and advances requiring an even more adaptive and sophisticated workforce. There is a need for a newly developed workforce of electronic resource library staffs, information managers, system interrogators and training and education providers to conceive, build and implement a wide array of information technology. Mount Kenya University Library has most of the ICTs suitable 6or use in libraries and should use them for the efficient and effective provision of information to its users.

Utilization of ICTs in Mount Kenya University Library by the staffs is inadequate as only the library staffs who provide certain service know how to use the relevant ICTs for that service. The use and applications of ICTs requires library staffs with skills and knowledge. Mount Kenya University Library staffs are not fully utilizing the ICTs in their office because of their varying levels of ICT skills. This research has established that Mount Kenya University library staffs have varying and limited ICT skills, and that there is need to train the library staffs at all levels in order to achieve effective and efficient use and application of ICTs. The library should establish a central training office for training of its staffs. Information communications technology solution will only be successful if they directly focus on the workforce that is expected to satisfy the critical information needs of the library users.

Mount Kenya University library should train its staffs at the same pace as it is acquiring and developing its ICTs. Dole and Stalker (1996) too pointed out that libraries should devote some of the resources to training their workers. In that regard, Mount Kenya University Library should adapt and devote some resources every year in order to have continuous training on ICTs considering how dynamic they are. Training should be considered important for all the levels of library staffs because their main objective is to make available information to the library users. Library staffs that are resisting technology must be brought on board and sensitized on its worthiness.

UNESCO Asia-Pacific Regional Bureau for Education (2002) indicated that, Universities are entering into partnerships with the private sector, particularly the IT industry, in order to help maintain operation and financial viability of ICT-based education programmes. This ICTs programmes must be sustained and developed on a long-term basis. Mount Kenya University Library has already indicated its plan of linking with other higher institutional libraries and national libraries for information provision; it should include training as a joint venture. Kaniki (1999) recommended that, "it will be a waste of limited resources for each institutions and library to develop its own courses as the needs for training appear to be similar". Mount Kenya University Library therefore should work together with other institutions that have ICTs training needs within the country.

Gallant investment in ICT in libraries is required in relation to library resources. As such, library staff must be in the know of all resources held in the library and how ICT foster their utility. Academic libraries must subscribe to all e-resources which will enhance ICT implementation and promote user-friendliness in the library set up.

\section{REFERENCES}

[1] Abbas, 1. 1997. The library profession and the Internet: implications and scenarios. Available: http://alexia.lis.uiux.e $\mathrm{du} / \mathrm{review} / 5 / \mathrm{abbas} / \mathrm{htm}>1$ (Accessed 8 April 2002).

[2] Abram, S. 1999. Let's talk about it: the emerging technology future for special librarians. Information Outlook. Available:

[3] http://www.findarticles.com/cfO/mOFEW/2 6/83912207/p1/article.jhtml? (Accessed 15 May 2002).

[4] Adeya, C. N. 2001. Information and communication technologies in Africa: a review and selective annotated bibliography 1990-2000. Available: http://www.inasp.org.uk .pubs/ict/sectionl.html (Accessed 4 May 2002).

[5] Aina, 1. O. 1994. Computer literacy: the need for librarians in the developing countries. Herald of Library Science 33 (1/2): $8-10$.

[6] Alreck, P. L. \& Settle, R. B. 1995. The survey research handbook: guidelines and strategies for conducting a survey. 2nd ed. New York: McGraw Hill.

[7] American Society for Quality. 2000. In-house training. Available: http://www.asq.org/ed/training/benefits.html (Accessed 10 December 2002).

[8] Avatech Solutions. 2002. Training return on investment - the real cost of no training. Available: http://www.avatechsoluti ons.com/aboutus/careers/ (Accessed 19 December 2009).

[9] Awa, E. G. 1996. The role of information technology in development: a case study of Nigeria [Dissertation 
Abstracts].

[10] Babbie, E. R. 1991. The practice of social research. 6th ed. Belmont: Wadsworth.

[11] Bill, H. K. \& Wanyama, P. 2001. Automation and its impact on the job satisfaction among the staff of the Margaret Thatcher Library, Moi University. Library Management 22 (6/7): 303-10.

[12] Bless C. \& Higson-Smith, C. 1995. Fundamentals of social research methods: an African perspective. 2nd ed. Kenwyn: Juta \& Company.

[13] Brandt, D. S. 2001. Information technology literacy: task knowledge and mental models. Library Trends 50 (1): 73-86.

[14] Burke, J. 1996. Using electronic discussion groups and the World Wide Web to deliver library instructional and promotional materials. ISAL '96, Shanghai. 1-4 September 1996. Available: http://oldweb.lib.sjtu.edu.cn/isal/isal 73.htrn (Accessed 15 May 2002).

[15] Cannon, B. 1995. Training needs for tomorrow's public librarians. Southeast Librarian 45 (2): 68-70.

[16] Capeles-Roman, A. 1997. Knowledge skills, and attitudes of University professors at the Rio Piedras campus of the University of Puerto Rico [Dissertation Abstracts (Pro Quest)]

[17] Chisenga, J. 1999. Global information infrastructure and the question of African content. Proceedings of the 65th IFLA Council and General Conference. Bangkok, Thailand. 20-28, August 1999.

[18] Chisenga, J. 2001. Information management unpublished seminar paper. Pietermaritzburg: University of Natal, Information Studies Programme.

[19] Dane, F. C. 1990. Research methods. California: Brooks Cole.

[20] Desai, C. M. 2002. Continuing education needs of science and technology librarians: results of the 2001 STS Continuing Education Committee Survey. ["Library Information Science Abstracts". Issues in Science and Technology Librarianship (34): spring).

[21] Dole, W. V. \& Stalker, D. S. 1996. Staff development and training in a team environment. ISAL '96, Shanghai. 1-4 September 1996. Available: http://oldweb.lib.sjtu.edu.cn/isal /isaI76.htm (Accessed 15 May 2002).

[22] Donovan, B. 2001. Acquiring the skills and knowledge needed to take advantage of the potential and information: School of Information Management-research progress working paper IMRIP 2001-2. Available: http://www.lmu.ac.uk/ies/im/research/2001 (Accessed 4 December 2002).

[23] Durrheim, K. 1999. Research design. In: Terre Blanche, M. and Durrheim, K. (eds). Research in practice: applied methods for the social sciences. Cape Town: University of Cape Town, pp.29 53.

[24] Fatuyi, E.O. A. 1998. Librarians, computers and the global information management. Library Focus 15/16: 52-60.

[25] Fors, M. \& Moreno, A. 2002. The benefits and obstacles of implementing ICTs strategies for development from a bottom-up approach. ASLIB Proceedings 54(3): 198-206.
Available: http://lucia.emeralinsight.com (Accessed 14 November 2002).

[26] Garrod, P. 2001. Staff training and end-user training issues within the hybrid library. Library Management 22 (1-2): 30-36.

[27] Gregory, G. 2000. The importance of automation literacy. Information Today. Available: http://www.findarcticles.com/ cf 0/m3336/1 17/58565129/pl/articles.jhtml (Accessed 14 May 2002).

[28] Israel, G. D. 1992. Determining the sample size. Available: http://edis.ifas.ufl.edu/BODDY PD006 (Accessed 3 September 2002).

[29] Joint Information Systems Committee. 2001. London further training needs survey, June 2001. Available: http: www.rsc-London.ac.uk/tna/support.html (Accessed 15 May 2002).

[30] Kaniki, A. M. 1996. Virtual digital libraries: whither South Africa academic libraries? Conference on Information Technology in Tertiary Education, Cape Town, University of Cape Town 10-12 April, 1996. Available: http://www.uct.ac.za/conferences/citte/abstract.htm (Accessed 15 May 2002).

[31] Kaniki, A. M. 1999. Internet use and training needs of staff of the esAL consortium, KwaZulu-Natal, South Africa: partnership between historically disadvantaged and advantaged institutions (HDI's and HAI's). 65th IFLA Council and General Conference, Bangkok,

[32] Thailand, 20-28 August, 1999. Available: http://www.ifla.org/IV/ifla65/papers/041115e. htm (Accessed 15 May 2002).

[33] Kanjee, A. 1999. Assessment research. In: Terre Blanche, M. and Durrheim, K. (eds). Research in practice: applied methods for the social sciences. Cape Town: University of Cape Town, pp. 287-306.

[34] Kerlinger, F.N. 1973. Foundations of behavioural research. 2nd ed. New York: Holt Renhalt.

[35] Lancaster, F. W. \& Sandmore, B. 1998. Technology and management in library and information services. ["Library and Information Science Abstracts", Library Review 47 (1\&2): 45-6].

[36] Langerman, S. 2001. The information profession in the information age ["Library and Information Science Abstracts," Information and Librarianship 29 (1): 45-8].

[37] Leedy, P. 1997. Practical research: planning and design. 6th ed. New York: Macmillian.

[38] Lesk, M. 1997. Practical digital libraries: books, bytes and bucks. San Francisco: Morgan Kaufmann.

[39] Library and Information Commission. 1998. Building a new library network: a report to government. Available: http://www.lic.gov.uk/publications/policyreports/building/tg 9.htrnl (Accessed 16 May 2002).

[40] Lor, P. 2000. Libraries in the African renaissance: Africa experience and prospects for survival in the information age. Information and Library Review 32: 213-236.

[41] Maphakwane, G. G. 1996. The management of change in academic libraries: a case study of the impact of automation at 
the University of Botswana Library. MLIS thesis. Gaborone: University of Botswana.

[42] Meadows, A. 1., Gordon, M. \& Singleton, A. 1982. Dictionary of new information technology: a guide to information processing for industry, business, education and home. London: Century.

[43] Moore, S. 2001. Libraries to libraries: managing public access computer labs in an academic library environment. ["Library Information Science Abstract" Reference Librarian (74): 207-20].

[44] Morriello, R. 2000. A university library faces up to multimedia. ["Library and Information Science Abstracts,"] Bulletin-d' Information-de-l' Association-des-Bibliothecaires Francais 186 (first quarter): 46-50].

[45] Mouton,1. 1998. Understanding social research. Pretoria: 1.L. Van Schaik.

[46] Mulira, N. K. 2000. Connecting Makerere University into the global information infrastructure. Proceedings of a workshop held at international conference centre, Kampala-Uganda 19-20 April 2000. Available: http://www.makerere.ac.ug/ma kict/documents/sida/proceedings/muict/strategy.htrn\#paper mabile (Accessed 10 December 2002).

[47] Munoo, R. 2000. A survey of compact disk-read only memory (CD-ROM) technology application in South African university libraries. MIS thesis. Pietermaritzburg: University of Natal.

[48] Nawe, 1. 2000. Using information and communication technologies in Tanzania: responses of information professionals. Information Development 16 (1): 24-28.

[49] Nawe, J. 200la. The future of library and information services in Tanzania. Library Review 50 (30): 138-145.

[50] Nawe, J. 2001 b. Leadership challenges in higher education libraries in East Africa. Information Development 17 (1): 29-34.

[51] North Lincolnshire Libraries. 2001. Annual Library Plan. Available:http://www.northlicxs.gov.uk/libraryplan/section3 /10.htm (Accessed 15 April 2002).

[52] Papandrea, V. A. 1998. Managing reference services in the electronic age: a competing values approach to effectiveness. In: Iyer, H. (ed.) Electronic resources: use and user behavior. New York: Haworth, pp. 111-126.

[53] Peterson, R. A. 2000. Constructing effective questionnaires. Thousand Oaks: Sage.

[54] Powell, R. R. 1991. Basic research methods for librarians. 2nd ed. New Jersey: Ablex.

[55] Prytherch, R. 2000. Harrod's librarians' glossary and reference book: a directory of over 9,600 terms, organizations, projects and acronyms in the area of information management, library science, publishing and archive management. 9th ed. Aldershot: Gower.

[56] Qi, Z. 1996. Side-effects of high and new information technologies: new problems university libraries have to deal with. ISAL '96, Shanghai. 1-4 September 1996. (Available) http://oldweb.1ib.sjtu.edu.cn./isallisa176.htm (Accessed 15 May 2002).

[57] Ratcliffe, F. W. 1995. Collection management in a period of change. ["Library Information Science Abstracts," Cademas-BAD (3): 9-21].

[58] Richvalsky, 1. \& Watkins, D. 1998. Design and implementation of a digital library. ACM Crossroad Student Magazine. Available: http://www.acm.org/crossroads/xrds52/diglib.html (Accessed 5 November 2002).

[59] Rowley, J. 2002. Using case studies in research. Management Research News 25 (1): 16-27.

[60] Rubin, R. E. 1998. Foundations of library and information science. New York: NealSchumann.

[61] Sada, E. 1999. Training users in the electronic era. Information Outlook. Available: http://www.findarticles.com $\operatorname{lcf}($ Accessed 14 May 2002).

[62] Sharif, A. \& Mahmood, K. 2001. Impact of computer training on professional library activities in Pakistan. Information Development 17 (3): 173-7.

[63] Simmonds, P. L. \& Andaleeb, S. S. 2001. Usage of academic libraries: the role of service quality, resources, and user characteristics. Library Trend 49(4): 629-634.

[64] Soong, S. C. 1998. Revitalizing academic libraries for the 21 st century. Paper presented at the International Conference on New Missions of Academic Libraries in the 21 st Century. Beijing, China, October 25-28, 1998. Available: http://www.lib.pku.edu.cni98conf/paper/a/SamsonSoong.ht $\mathrm{m}$ (Accessed 18 June 2002).

[65] Soy, S. K. 1997. The case study a research method. Available: http://www.gslis.utexas.edu (Accessed 5 December 2002). Special Libraries Association. 1998. As non-traditional becomes typical (librarians) Information Outlook. Available: http://www.findarticles.comlcf (Accessed 14 May 2002).

[66] Steele, C. \& Guha, M. 1999. Staffing the digital library in the 21 sI century. Available: http://anulib.anu.edu.au/about/steel e/digital library.html (Accessed 15 May 2002).

[67] Stephen, P. \& Hornby, S. 1995. Simple statistics for library and information professionals. London: Library Association.

[68] Stover, M. 1999. Leading the wired organization: the information professionals' guide to managing technological change. New York: Neal-Schumann.

[69] Subramanian, 1. M. 1998. Patron attitudes toward computerized and print resources: discussion and considerations for reference service. In: Iyer, H. (ed.) Electronic resources: use and user behavior. New York: Haworth, pp. 127-138.

[70] Totterdell, A. \& Harrison, C. T. 1998. The library and information work primer. London: Library Association.

[71] Tran, L. A. 2001. Training in the implementation and use of electronic resources: a proposed curriculum for Vietnam, part 1. Journal of Library and Information Science 42 (3): 257-263.

[72] Van Zeijl, F. 1998. Commercialisation and privatisation may lead to disintegration of library services and the undermining of democracy: librarians must man the barricade to defeat unhindered access to information.["Library and Information Science Abstracts", Bobliotheek Blad 2 (6): 16-17].

[73] Wema, E. F. \& Nawe, 1. 2000. Prospects and traumas of 
computer-aided services in University Libraries of Dar es Salam. Information Development 16 (3): 155-162.

[74] Whitney, G. \& Glogoff, S. 1994. Automation for the nineties: a review article. Library Quarterly 64(3): 319-331.
[75] Woodward, 1. 1997. Retraining the profession, or over the hill at 40. American Libraries 28 (4): 32-34.

[76] Yin, R. K. 1994. Case study research: design and methods. 2nd ed. Thousand Oaks: Sage. 